\title{
FROM ANCIENT GREEK LOGOS TO EUROPEAN RATIONALITY
}

\begin{abstract}
Because of history, culture, and politics, European identity has its archetypical elements in ancient Greek culture. Ancient Greek philosophy brought Logos to fore and defined it as the crucial problem and the postulate of the human. We translate the Greek term Logos in English as reason or rationality. These terms, however, do not cover the semantic field of Logos since this includes, among other things, order of being, ground, language, argument etc. The juxtaposition of Logos (reason) to myth makes up the matrix of rationalism. Ancient Greek culture, however, was a culture of Logos (reason) as well as of myth and had enough room for forms, gods, and heroes, for science, poetry, and religious festivities. While ancient Greek culture seems to follow the logic of forms, modern European culture follows the logic of things.

Plato criticizes myth and, at the same time, he sets out a philosophy of myth. He follows the principle of 'giving reason' (logon didonai) about things, as his master Socrates did. He establishes dialogue and defines dialectics as the science of principles and ideas and their relations to the things of this world. Aristotle did not accept Plato's interpretation of Logos. He considered dialectics only as a theory of argumentation and defined his 'first philosophy' or 'theology' as the science of highest Being. His program of rationalism is based on ontology and accepts the primordial relation of $\underline{\text { Logos, }}$ life, and order of things.

European modernity begins in philosophy with Descartes' turn to the subject. Descartes defines the main elements of European rationality and their problems. He brings to fore the human subject as the 'I' that is free to doubt about everything it can know except itself. Knowledge has to consolidate the power and the mastery of humans over things and nature. Besides, the distinction between soul and body in terms of thinking thing and extended thing does not allow a unique conception of the human. Especially Kant and Hegel attempted to eliminate the impasses of Descartes' and of Cartesians. While Kant defined freedom as the transcendental idea of reason, Hegel highlighted the reconciliation of spirit and nature.

Nowadays there is a confusion regarding rationality. The power of humans over nature and over other humans as nature is increasing. We have lost the measure of our limits. Perhaps we need the ancient Greek grammar of Logos in order to define the measure and the limits of modern European rationality.
\end{abstract}

Keywords: Logos, reason, rationality, myth, dialectics, order, human identity, subject, freedom, nature, Plato, Aristotle, Descartes, Kant, Hegel, idea of Europe. 


\section{Introduction: Politics and Culture}

The idea of Europe almost belongs to everyday vocabulary, but its semantics is fluid, even though there is the impression that it is not so. For politicians the idea of Europe seems to be clear, since it expresses the unity of European people as a reality in process and as an ideal as well. It is suggested that this reality embraces the common political actions of European people for freedom, prosperity, peace, and education. Nevertheless, behind political actions, goals and rules, there is a long and alive tradition of European culture including cultural goods, values, and expectations that belong to the common horizon of life. It is plain that we have to take into account these elements and to set out a broader interpretation of the idea of Europe that would allow European people to recognise their contribution and relation to European culture and to participate in the various activities intending to make Europe the common home of the Europeans. In fact, the aforementioned European culture seems to be a differentiated and open unity, the main components of which are ancient Greek culture, Christian religion, and Roman law. These components are the spiritual property, the offer, and the proposal of Europe to itself and to humankind for understanding the values and the dangers of human life. Nevertheless, the idea of Europe is not a theoretical conception of what European culture is, or a projection into a future for everyday purposes. On the contrary, it is connected with the value-based attitude of citizens towards politics, culture, and humanism and with the critical awareness and participation in public life.

When we raise the question of what the 'identity' of the idea of Europe is, we have to refer to ancient Greek culture, not only because ancient Greek culture is the universal heritage of humankind; but because the alleged 'identity' of the idea of Europe has its archetypical element in ancient Greek culture and has been formed through renewing the relation to it. Ancient Greek culture has not only offered important creations in poetry, philosophy, history, art, or rhetoric; it has also brought to the fore important conceptions concerning the order and the meaning of human life, like political freedom, isonomy, the equal right to public speech, justice, measure, and Logos. The most important discovery of the ancient Greeks is the idea of Logos that makes up the crucial problem and the postulate connecting ancient Greek culture together with European culture. We translate Logos in English usually as reason, or rationality. These terms, however, do not cover the whole semantic field of Logos. The main problem does not concern the translation, but it is related to the difference of human self-understanding and understanding of the world. Generally speaking, Logos can be reason and language, ground of things and order of Being, discourse, and discursive rationality. The semantic focus depends on the semantic interrelations within a concrete context.

Even though Logos characterises ancient Greek culture, it is ancient Greek philosophy that has attempted to develop a theoretical account of it. In fact, ancient Greek philosophers developed different theoretical accounts, distinguished through a critique that never questioned either Logos or the primordial interrelation of life and thinking. For ancient Greek philosophy, the question of Logos refers to reality and to the human attitude to- 
wards reality, and it is not a simple problem of semantics. It is the connection to this reasoning attitude towards life and the world that offers to the idea of Europe historical depth as well as openness and perspective.

In this paper, I shall explore some structural characteristics and transpositions in the philosophical theorising about $\underline{\log O S}$ that manifest the common principle and the difference of European rationality from ancient Greek Logos.

\section{The Hermeneutic Outset}

Focusing on Logos and Reason does not mean either the absence of reason or rationality from other cultures or a rationalistic interpretation of ancient Greek culture in terms of European rationalism. The common foundation of cultures is the conditio humana, the human condition including the metaphysical need of the human to give a meaning to its life and the world and to create an order of life corresponding, as far it is possible, to this meaning. Max Weber has brought to the fore the various forms of rationality in religions and cultures and has emphasised that the rational need of giving a meaning to the world makes up a constitutive characteristic of humans (Weber, 1972, p. 307).

Nevertheless, the rationality of religions and cultures is mediated through scientific research, while in the case of ancient Greek culture Logos makes up a characteristic of the self-consciousness of the people that created this culture. The ancient Greeks conceived the reasoning character of the human and, at the same time, they became conscious of the relevance of their discovery, so that they considered $\underline{\log o s}$ as a content with value in itself, and they created concrete cultural expressions according to Logos, like philosophy, history, and the sciences. Philosophers searched for the way to truth according to Logos, they discovered method and concept, dialectics and logic, ethics and politics. In ancient Greek culture, a novel view of the human and of the world emerges, because the human is 'here' and the world is not determined anymore through the relation to mythic powers. The human and the world make up an order with $\underline{\text { Logos, }}$ with reason, that becomes the unique problem of philosophy. Husserl admits that the spiritual birth of Europe happens in ancient Greece, when philosophers introduce a new attitude towards the world, namely the theoretical attitude, that differs from the practical-mythic one, because it is a self-purpose purpose in itself and shapes the work of philosophy, namely of the universal science of the world (Husserl, 1976 a pp. 326, 328, 331).

In this way philosophy constitutes the identity of European culture and, at the same time, it belongs to it. Since philosophy has as its work to explain the question of $\underline{\log o s}$, of reason, philosophy itself holds the book of the open accounts of reason in European culture. This consciousness of the importance of reason makes up the foundation of the differentiated continuity of reason in European culture. Even though the juxtaposition of $\underline{\operatorname{Logos}}$ against myth constitutes the origin of rationalism, the fact is that ancient Greek culture was the culture of reason as well as myth; it made space for the critique of myth and for tragedy, for art and philosophy. It was exactly the creative plasticity of the ancient Greek spirit that allowed the human to express its relation to itself and to the world in the different expression of reason and myth. In the continuity 
of reason that is explored in philosophy there is a turning point indicated by Descartes as the leader of European rationalism and the 'grandfather of the French revolution' according to Nietzsche's words (Nietzsche, 1966 ${ }^{\mathrm{a}}$, p. 649). It is the turn towards the human subject as the 'I' that defines the order of the human and of the world as an epistemological relation.

Max Weber has characterised the course of occidental culture as a course of detachment and rationalisation due to a bundle of factors attributed to religion, science, economy, science, bureaucracy. Some of Max Weber's remarks allow the conclusion that, in ancient Greek culture, things exist and receive meaning through their essential relation to forms, to gods, to heroes, to the human. Modern European culture undermines this logic of forms and ascribes a specific sense in the logic of things (Weber, 1972, p. 250). So, rationalisation develops together with reification, and things lack every other meaning except that of exploitation and mechanistic relation. This distinction of two logics, namely of the logic of forms and of the logic of things, does not indicate that there are two separate epochs of European culture; it only points to the fluid tension existing in the relation of the human to the world and, at the same time, it points to the open historicity and to the open worldness of the human.

If we use this distinction as a hermeneutic outset, we can ascertain that the differentiation of modern European culture from ancient Greek culture is obvious in terms of abolishing the idea of ontological order and in the radical consciousness of the freedom of the human, of the human concretely considered as the knowing and acting subject.

\section{3. $\underline{\text { Logos }}$ and Myth - Logos and Order}

In ancient Greek philosophy an order of the meaning of Logos emerges, which is pertinent to the answer to the fundamental question 'what is?'. Logos is the primordial corresponding order of the human and the world. The human approaches this order through thinking and expresses it through language indicating that beings are as well as what beings are in their essence. Since philosophy appears as a peculiar approach to the world and, at the same time, as a peculiar utterance of Logos as language, it becomes juxtaposed to poetry and myth, since they have their origin in inspiration and imagination. Nevertheless, except for this justified juxtaposition, there is also a primordial connection between them. So, myth and metaphysics exist together in Parmenides' poetry and, at the same time, they become different. The critique of myth, even in its radical expression, does not abolish myth, because the scientific-rational spirit with its abstraction from the forms exists, but it has not yet become dominant, as it happens in modernity.

In ancient Greece, Logos remains human and myth is also human, since myth is the creation of the old poets and not the revelation of a transcendent Being that defines and restrains forms. In this aspect myth is present in ancient Greek poetry, art, and religion and it feeds the logic of forms. In fact, this logic of forms characterises ancient Greek culture, and not even ancient Greek philosophy abandons them. Without doubt, Plato is the philosopher who investigates myth as an independent problem of reason. Through his critique of myth, he comes to a philosophy of myth that creates a favourable field for the 
emergence of some fundamental elements of rationalism. Plato started as a poet and was acquainted with myth and its relevance for life. Later, he became a philosopher and he formulated a harsh critique of myth in order to restrain anthropomorphism and to oppose dialectics to the extensive mythic narrative. Nevertheless, Plato remains a philosopher with poetic inspiration. While banishing poets from his ideal state, Plato himself is confident that he realises the essence of poetry through dialogue, since his speech divines truth through the inspiration of the philosophic muse (Plato, 1961 a , 676b6-7).

The ontological connection of philosophical speech to ideas and the truth allows Plato to define philosophical myth as the probable narrative of becoming. But this is a narrative the limits of which are examined, while its place within philosophical dialogue has been determined (Plato, 1961 ${ }^{\mathrm{d}}, 29 \mathrm{~b}-\mathrm{d}$ ). The consequence is the ontological re-evaluation of myth as well as the poetical re-evaluation of $\underline{\text { Logos, }}$, since myth presents truth in picture, while Logos (reason) is elevated to the divine level from which poetry draws its inspiration. So, Plato finds his own solution for the problem concerning the limits of Logos. It is worth mentioning as an example the myth of recollection from Plato's dialogue Phaedrus. This myth narrates that the soul has seen the eternal ideas during its pre-existence. When the soul was embodied, it forgot what it had seen in its previous existence. It is the work of philosophy to help the human soul recollect the truth of ideas. This myth explains within the Platonic context how the soul knows ideas that are not tangible things. At the same time, it includes the origin of the rationalistic view regarding the priority of logical elements in relation to experience.

Anyway, dialogue itself relies on the priority of Logos. Plato, as well as his master Socrates, follows the principle of logon didonai, namely of 'giving reasons' about things (Plato, 1961 $\left.{ }^{\mathrm{d}}, 534 \mathrm{~b}\right)$. But this principle points to an interactive performance, since it presupposes a common investigations and a mutual examination of the arguments by two persons. Therefore, this principle offers a distinction between critical dialogue and anticritical authority in knowledge and action. As Aristotle writes, while examining the arguments and searching for definition and universals, Socrates opened up a new way of thinking (Aristotle, 1963, 987b-988a, 1078b17-30). Plato followed this conscious turn of Socrates towards definition and the universal and he achieved the conscious discovery of the concept. In the view of Max Weber, this discovery was the greatest contribution of the ancient Greeks to the development of scientific thinking (Weber, 1973, p. 596).

Nevertheless, a concept does not make up the only component of the idea. First of all, the idea is the ontological universal that offers a solution to the problem concerning the relation between one and many, since the many are what they are through their participation in the one. Plato transposes the problem on the level of the two primordial principles, namely the One and the Indefinite Dyad. The ontological priority of ideas and principles defines dialectics as the fundamental philosophical science of Being and keeps together method and intuition. In this aspect, 'method' is not some instrument for every purpose (Plato, $\left.1961^{\mathrm{c}}, 510 \mathrm{~b}\right)$. On the contrary, 
method is the appropriate way of thinking that leads to the manifestation of truth. Nevertheless, the crucial point and moment of this manifestation can hardly be described through language, since it is an event accessible to intuitive vision (Plato, VII Epist, 341c-d). In epistemological terms, dialectics is the summit of sciences; it founds the sciences of the second class, namely mathematics, and defines dialogue as the formulation and examination of arguments concerning the highest issues of human life. Nevertheless, this definition does not lead to the marginalisation of desire. On the contrary, Plato ascribes to desire ( $\underline{\text { eros }})$ the power of elevating the soul to the idea of Beauty, which is 'the refuge of the power of the idea of Good' (Plato, 1961 ${ }^{\mathrm{b}}$, 210d-211c; Plato, 1961 a ,64e-65b).

Plato sets out a comprehensive program of rationalism that is based on the primordial ontological interconnection of the two principles, namely the One and the Indefinite Dyad, to the ideas, to nature, to soul, to political state. Further, the 'appropriate' unity and order of every field fits into the order of the whole that has its primordial point of relations in the 'idea of Good'. This idea is beyond essence, and it affords truth, possibility of knowledge, and value. Since all things of this world participate in other ideas, they receive through these ideas ontological and axiological quality (Plato, $\left.1961^{\mathrm{c}}, 508 \mathrm{e}-509 \mathrm{a}\right)$. It is plain that Plato establishes an ontological model of relations. The relation among the specific idea and the sensuous things is called participation as regards the sensuous things, while it is called the presence of idea in the sensuous things. This consideration includes indirectly a conception of judgement. For example, the relation of the idea of beauty to the beautiful things of this world points to the priority of the predicate towards the subject. So, in the judgement 'this rose is beautiful', the predicate indicates the essential 'one' that is also 'unique', namely it points to the idea of the beautiful.

Taking into account Plato's conception of participation and presence, we have to underline that the human does not have this ontological order of relations in terms of an object opposite to itself, as is the case in the modern split of subject-object. In fact, the human participates in this order and, at the same time, it is invited to establish through its own activity the appropriate order in the soul, in the city, in its whole life. The privilege and the work of the human are to discover and to know the primordial order in which humans participate. In this way, human life becomes a life with reason and spiritual joy. While discovering the primordial order, the human also discovers itself as participant of this order. Therefore, the dignity of the human is primarily defined through the participation to this primordial order and not through any achievements.

Nonetheless, Plato's comprehensive program creates new problems through the solution of old ones. Subsequently, Aristotle, the most famous of Plato's pupils, undermined his master's program. He criticised the exaggerated ontological interpretation of $\underline{\operatorname{Logos}}$ (reason) as well as the unifying principles and the idea of the Good. His argumentation concerns the very existence of the ideas on an ontological level beyond sensuous things. His famous argument disrupts ontology by reducing it to a semantic pluralism: For example, 'Good' is said in many ways; consequently, the term 'Good' is not some exclusive essence 
existing beyond the concrete things that are good. As regards the judgement, priority is ascribed to the subject, while the predicate is deprived of the priority it had in Plato's philosophy.

So, Plato's comprehensive ontology of beings and relations is broken down, the order of things is relegated from the transcendent level to the cosmological one, to this world, to nature, to city. Nevertheless, Aristotle avoids the naturalistic reduction of Logos (reason), since he defines the first 'moving unmoved' as 'the thinking of thinking' (Aristotle, 1963, 1074b34-35). Aristotle develops a pluralistic ontology and argues that the essential element is in things themselves and not in transcendence (Ibid, 1032b1-2, 1037b25-27). These novelties cut down on Plato's definition of dialectics as the highest science of principles and ideas and of their relation to things. So, Aristotle defines dialectics as a peculiar investigation of argumentation, without abolishing its truthful intention, as it had been established through Socrates and Plato. In Aristotle's consideration the highest science is the science of Being and is named 'first philosophy' (prote philosophia) and sometimes 'theology' (theologia), since the highest is the Divine Being. In Aristotle's pluralistic ontology, sciences have their own principles and shift attention from transcendence to experience (Aristotle, 1968, Anal. post., 87a39-87b1). Nevertheless, they are not detached from ontology. Aristotle and Plato do not separate philosophy from science. Therefore, they consider the (philosophical) science of principles, of the highest and ultimate Being, as the highest science. It is worth mentioning that even logic remains connected to ontology for Aristotle, even though logic tends to abstraction.
Aristotle considers knowledge as the result of methodical investigation as well as of restraining transcendental connotations. Indeed, Aristotle's epistemic and epistemological considerations bear characteristics that foreshadow the modern scientific spirit. One could mention here considerations about the systematic character of scientific knowledge, the distinction between facts and explanation, the role of empirical description. Further, Aristotle established the independent philosophical research of ethics, of the theory of argumentation, of political philosophy, or of sciences like biology, embryology, zoology, and others. Nevertheless, Aristotle does not endorse some version of scientism in modern terms, namely the conception that only science can provide answers to the main questions of life. In Aristotle's view, only philosophy can explore the order of being qua being (on e on) and, at the same time, describe the rational order of knowledge as well as of science. His first philosophy or theology manifests that the highest Being (Aristotle, 1963, $1064 \mathrm{~b} 2-5)$ is the point of the teleological relation of all things, of the celestial spheres, of natural elements, of living nature, and of the human too.

Aristotle's program of rationalism rests upon the primordial ontological connection of reason, species, and life, human life included. The human considered as a 'living being', namely as a being moving itself (Aristotle, 1960, 252a11-16), just like the other living beings on earth, belongs to living nature that is subject to the order of becoming and decay. At the same time, the human is endowed with

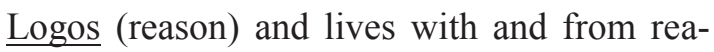
son in political society, in family, in friendship. Moreover, the human is endowed with 
intellect (Nous) and related to the Divine Being that lives beyond process and change in its actuality of 'the thinking of thinking' (Aristotle, 1963, 1072b26-30). Since Aristotle criticised the transcendent idea of the Good as a universal principle, he considers the category of relation (pros ti) as a component of virtues indicating the relation to the self or to others. Wisdom is the only virtue that does not need the relation to others, because it is the activity of intellect towards the Divine Being.

In fact, this activity presupposes the cognitive acquaintance with the whole of reality, at the summit of which is the Divine Being. So, wisdom as the characteristic of the theoretical form of life indicates the activity and the purpose of philosophy. Aristotle draws attention to the main reasoning activities of the human. Theory (theoria) is the disinterested search for truth (Aristotle, 1970, Eth., 1177b1-2), action (praxis) is the moral and political activity performed in the light of the Good and fulfilling the richness of life. Creative activity (poiesis) creates things and artworks (Aristotle, 1970, 1140a2-16).

Also, for Aristotle human activities take place within an ontological and cosmological interconnection that has a differentiated relation to the meaning of life. The human realises its intrinsic purpose (telos) through the aforementioned activities within social and political relations that exist 'by nature', namely they are essential to human life. Consequently, they are not constituted by humans; humans carry out their forms of life within them and realise their primordial relation to the teleology of the whole.

As it is obvious, Plato and Aristotle set out two programs of rationalism with an onto- logical foundation. Both of them retain the priority of the ontological universal as well as the correspondence of the human to the order of reality. As seen, the broad differences between the two programs do not marginalise the common perspective of intuitive access to the primordial source of ontological meaning. Plato mentions love and intuition, Aristotle points to theoretical intuition as an intrinsic activity of the soul. These aspects precede method, and retain the logic of forms.

The conception of ontological and cosmological order as the primordial frame of life is characteristic for ancient Greek philosophy. Later, it makes up the foundation of the conception of order ( $\underline{\text { ordo }}$ ) in the philosophy of the Middle Ages, namely of the conception about the order of beings that are created and preserved and ruled by God. This conception will be deconstructed in modernity. Nevertheless its merits and problems are like splinters still present in modern and contemporary philosophy.

\section{Rationality and Subject - Subject and Freedom}

The formation of European rationality is a complicated event extended over the whole of European culture. In philosophy, the beginning of modernity is connected with Descartes' name, because Descartes signals with his turn to the subject 'the primordial foundation of philosophical modernity', as Husserl writes (Husserl, 1976, p. 438). Nevertheless, it is worthwhile to consider how this turn has been understood in Neohellenic philosophy. We take as an example the view of Nikolaos Kotzias who lived in $19^{\text {th }}$ century, was a critical student of Friedrich Wilhelm Schelling, 
and, consequently, was acquainted with the question about what philosophical modernity is. Kotzias maintains that there is no rupture between ancient Greek philosophy and modern philosophy; on the contrary, their continuity is obvious, because the human is taken as the principle and the starting point of theorising in both cases. In his view, the difference between them consists in the relationship between spirit and nature; while ancient Greek philosophy brings to the fore the 'identity' of spirit and nature, modern philosophy promotes the split between spirit and nature (Kotzias, 1878, p. 490). Kotzias admits that Descartes 'has put rationality, namely the thinking subject' as the principle and the foundation of philosophy. But he criticises him by arguing that this rationality is not 'right', because it denies reality and remains hemmed within the subject (Ibid, p. 6).

However, we have to take into account that the human is not taken as the principle of philosophy with the same meaning in both cases. For ancient Greek rationalism, the human is the participant of the primordial order of Being and it realises its participation in this through the order of its own life. It is exactly this primordial ontological interrelation that protects ancient Greek Philosophy from the abstraction from the human as well as from the danger of the subject-object split. Anyway, Socrates' turn from nature to humans as well as the focusing upon the question 'what is the human?' is decisive events in the history of ancient Greek philosophy, because they take place at a time when the research of nature trends to become independent from human reality.

Maybe in this sense there is a coincidence with Descartes' philosophy, similar to that of Socrates'. Anyway, as far as the question about the human is concerned, Socrates' rationalism is different from that of Descartes' rationalism, since the former focuses on ethics, while the latter aims at grounding knowledge. For Socrates, the question of the human is an anthropological one, since it takes into account some ontological elements, like the universal of justice or the universal of the sacred, which do not depend on human input. Therefore, they do not allow the total reflection of thinking onto itself, as this becomes possible primarily with the philosophers of German idealism. In Descartes' view, however, the human as the subject, namely the 'I' makes up the point at which rationality is gathered and concentrated; consequently, it leads to anthropocentric considerations. For, even God undertakes the burden of solving problems defined by the subject, like the objectivity of the world or the guarantee of truth according to the prerequisites of the subject.

In Descartes' philosophy the elements of the logic of things emerge gradually, as it is obvious in his conception of the human. Nevertheless, this logic manifests the world as the space of things and enlarges the practical chances of the human. Further, the view that the human is a subject means that only the human is a subject. Descartes' version restricts the conception of subject and abolishes the rich ontological and logical consideration of Aristotle, for whom a subject can be the human but not only the human. Besides, the distinction between methodology and ontology concerning the conception of the human is not made clearly enough by Descartes. While dealing with the question about the human, Descartes denies, among other qualities, the 
view that the human is a 'living being endowed with reason', since he interprets it as a psychological one; instead of it, he defines knowing consciousness as the main characteristic of the human (Descartes, 1969, VII, 27). In this way, Descartes does not consider the primordial relation of reason and life, and he answers questions as to what the 'I' is but not questions as to what the human is. The subject as the 'I' has the peculiar freedom not only to doubt everything except itself but also to deny the existence of those things which it doubts (Ibid, VII, 12).

Nevertheless, doubt is connected with a new conception of method. In this case, method precedes beings, because the firm application of method determines the existence of beings and relates them to the subject. This ideal of method has, indeed, contributed to the progress of modern science. However, while suggesting that the method of mathematics is unique and effective for every kind of knowledge, either mathematical or philosophical (Ibid, VI, 20-21), Descartes does not leave many possibilities for philosophy in terms of referring science to the world of life. The result is that science becomes autonomous towards the world of life. For Descartes, doubt does not have existential connotations (he has overcome them in his biography), but it becomes the principle of the methodical production of knowledge as regards God and also the things of this world (Ibid, X, 515). Since subject is the centre of reality and decides through its cognitive effort about Being, it corroborates its power as well as its domination over beings. Philosophy receives a new determination, since it has to promote the domination over nature, so that humans be- come 'masters and possessors' of nature (Ibid, VI, 62).

Even though the distinction of 'thinking thing' substance and 'extended substance' is useful as the starting-point for the development of specific sciences, it has negative consequences for the consideration of nature as well as humanity (Apostolopoulou, 2007). For, nature is considered to consist in bodies subjected under laws of mechanics and to constitute an object of science. Further, the human body is considered as a complicated machine (Descartes, 1969, VII, 229-230). After all, one ignores that nature is a vivid order of becoming and decay; at the same time, the unity of the human being is split. Under these presuppositions, there is no unique meaning connecting humans and nature in terms of life.

While the Cartesian program of rationalism introduces a split between subject and world as well as the radical freedom of the modern human, it is characterised by this calling for domination of the human upon the allegedly mechanical nature and by the destabilisation of philosophy. Because philosophy founds knowledge, but what it declares as the calling of the human is misleading, since nature is not only the space of things determined to be dominated by the human, since nature is the interrelation of life to which the human also belongs. Even though the Cartesian program brings the subject to the fore, it does not mean that the human is brought to the fore as a living and reasoning being -as 'soul' in Aristotle's terms (Aristotle, 1984, 431b21). For Descartes, the consciousness of the subject is only the object of rational psychology and it is considered as an object. In this aspect, the subject abolishes its existential depth. Further, 
the subordination of nature under scientific rationality excludes the possibility of a hermeneutics of nature that could establish nature as the realm of appearance manifesting a variety of qualities, of forms, colours, light, and darkness, namely of elements enriching human sensibility. In fact, this exclusive subordination will function as a foundation for the exaggerated development of objectivism as well as for the detachment of human interventions in nature from the question of meaning and of the order of human life on earth.

Anyway, philosophical proposals for revising the Cartesian program have not been lacking. Living nature has been a serious philosophical problem, for Leibniz, for Kant, for the philosophers of German idealism. In the twentieth century too, philosophical biology and philosophical anthropology have set out another proposal for considering the primordial interrelation of life to which humanity and nature belong without arguing that the human is merely a natural being. These Aristotelian interventions have not led to the expected results, at least up to now. It seems that the objective powers representing the ambiguous rationality of modernity are not willing to adopt a common meaning of reason and life. Nevertheless, modern philosophy does not offer only the Cartesian consideration of the connection between nature and freedom. Another perspective results from Kant's and Hegel's philosophy that has to tell the human something important about its relation to nature; it is the view that domination cannot be the principle defining the presence of the human in this world, because domination misunderstood as freedom without boundaries leads to catastrophe. It is plain that humans cannot live without consuming the material side of the world; but it is necessary to consider an order of freedom and recognition of protecting and in some way respecting the order of nature.

When Kant deconstructs the Cartesian program of rationalism, he releases the subject from the demand for domination over nature. While exploring the third antinomy of pure reason, Kant considers freedom in terms of cosmology and solves the antinomy through elevating freedom to a transcendental idea of pure reason (Kant, 1998, B561; B574). This transcendental freedom as the peculiar characteristic of reason is the source of practical freedom, the positive expression of which is the autonomy of will, namely the self-commitment of the will towards the moral law (Kant, 2003, pp. 58-59). In Kant's view, only the human expresses freedom in this world. Then the human could be considered as the being that can express the freedom of nature in terms of respect or protection of nature, so that nature preserves the status of the relational other of reason.

Philosophy has explained the primordial relation of humans and nature that cannot be abolished in favour of the alleged domination of humans over nature. Since humans have 'subdued' nature -according to the demand of modernity- in order to carry out their lives and to realise their own freedom, humans have the duty, since they are free beings, to offer nature more freedom and to let nature be what it is, namely relational and co-existing otherness of the human. Maybe this conception could be the conclusion from what Hegel writes about the reconciliation of spirit and nature (Hegel, 1975, 505f.), even though we are sceptical about the absolute terms of his discourse. Nevertheless, European rationalism 
includes a critique and meta-critique of its versions and shows that the problem concerning the order of reason and life remains still open after the breakdown of what was considered as metaphysics. The impasses of European rationalism do not imply the abandonment of reason. For, reason is the 'raft' of human life. Reason, freedom, reconciliation indicate the way in which modernity becomes enlightened about its limits and unforeseen consequences. The history of humankind is an open process of education; the lessons of modernity are not yet exhausted and can contribute to facing the problems of our days.

\section{Concluding Remarks}

If we consider the current situation of reason in terms of Aristotle's distinction of reasoning activities, we ascertain that there is a confusion of them. Theory has almost lost its primordial meaning as the search for truth, because the discovery of truth has been subordinated under the construction of truth. Philosophy, religion, and pure science retreat before techno-scientific knowledge. Action has lost its connection to the question about the meaning and the order of life, namely to that question which, according to Socrates, offers value and endurance to the presence of humans on earth. While the logic of things regards the world as the field of the infinite possibilities of the subject, the human itself tends to be reified; that means that the only living form that is a person is considered as a thing.

It is not obvious what the solution can be to these problems. Nevertheless, Logos, reason is a fundamental power, a chance and a duty that is always open and gives meaning to human effort and to human history. Perhaps we need the ancient Greek philosophical grammar of Logos in order to find the way from the infinite subject to the free human and to reconsider what it means to be human. The critique of reason, which does not intend to be a critique against reason, has always the purpose of finding the boundaries and the measure of reason in and with the world (Apostolopoulou, 1994). Nietzsche defined this as 'the fatal issue of Europe. Together with our fear for the human we have lost our love for the human, our respect towards the human, our hope for the human, really our will for the human. To see the human makes us tired. What is nihilism today if it is not exactly this? We are tired of the human...' (Nietzsche, 1966 ${ }^{\mathrm{b}}$, 789, Trans. from German G. Apostolopoulou). Nevertheless, we have to read these words against Nietzsche's prelude of the transition from the human to the superhuman, but as an instigation to reconsider what it means to be the human and to live as the human, without the alibi of the defeatism of reason.

\section{REFERENCES}

Apostolopoulou, G. (1994). He idea tou politikou anthropismou (The Idea of Political Humanism, in Greek). In M. Dragona-Monachou (Ed.), Political Philosophy Today. Proceedings of the Fifth Panhellenic Congress of Philosophy. Greek Philosophical Society. (pp. 25-34) Athens: Kardamitsa.

Apostolopoulou, G. (2007). Philosophy and Science at the 'End' of Cartesianism. News and Views(17), 8-29. International Academy for Philosophy. 
Aristotle. (1960). Aristotelis, Physica. Recognovit brevique adnotatione critica instruxit W. D. Ross. Oxonii: E typographeo Clarendoniano.

Aristotle. (1963). Aristotelis, Metaphysica. Recognovit brevique adnotatione critica instruxit W. Jaeger. Oxonii: E typographeo Clarendoniano.

Aristotle. (1968). Aristotelis, Analytica priora et posteriora. Recognovit W.D. Ross. Praefatione et appendice auxit L. Minio-Paluello. Oxonii: E typographeo Clarendoniano.

Aristotle. (1970). Aristotelis, Ethica Nicomachea. Recognovit brevique adnotatione critica instruxit I. Bywater. Oxonii: E typographeo Clarendoniano.

Aristotle. (1984). Aristotelis, De anima. Recognovit brevique adnotatione critica instruxit W.D. Ross. Oxonii: E Typographeo Clarendoniano.

Descartes, R. (1969). Euvres. Tom. 1-10. Publiées par Ch. Adam et R. Tannery. Paris. Vrin.

Hegel, G.W.F. (1975). Wissenschaft der Logik. Herausgegeben von G. Lasson. Zweiter Teil. Hamburg. Meiner.

Husserl, E. (1976). Die Krisis der europaeischen Wissenschaft und die transzendentale Phaenomenologie. Eine Einleitung in die phaenomenologische Philosophie. In: E. Husserl, Husserliana VI, 1-313. Haag. Martinus Nijhoff $\left({ }^{1} 1954\right)$.

Husserl, E. $\left(1976^{\mathrm{a}}\right)$. Die Krisis des europaeischen Menschentums und die Philosophie. In: Husserl, E. (1976).

Kant, I. (1998). Kritik der reinen Vernunft. Nach der ersten und zweiten Originalausgabe herausgegeben von J. Tim- mermann. Mit einer Bibliographie von H. Klemme. Hamburg. Meiner.

Kant, I. (2003). Kritik der praktischen Vernunft. Mit einer Einleitung, Sachbemerkungen und einer Bibliographie von H. Klemmer, herausgegeben von H. D. Brandt und H. F. Klemme. Hamburg. Meiner.

Kotzias, N. (1878). Historia tes philosophias apo ton archaiotaton chronon mechri ton kath' emas (History of Philosophy from the Most Ancient Times to Ours, in Greek). Vol. 3. Athens.

Nietzsche, Fr. (1966). Werke in drei Baenden. Herausgegeben von K. Schlechta. Muenchen. Hanser.

Nietzsche, Fr. $\left(1966^{\mathrm{a}}\right)$. Jenseits von Gut und Boese. In: Nietzsche, Fr. (1966). Bd.2.

Nietzsche, Fr. $\left(1966^{\mathrm{b}}\right)$. Zur Genealogie der Moral. Eine Streitschrift. In: Nietzsche, Fr. (1966). Bd. 2.

Plato (1961). Platonis, Opera. Tom. I-V. Recognovit adnotatione critica instruxit I. Burnet. Oxonii. E typographeo Clarendoniano.

Plato (1961 a). Philebus. In: Plato (1961), Tom. II.

Plato $\left(1961^{\mathrm{b}}\right)$. Symposion. In: Plato (1961), Tom. II.

Plato (1961'). Res publica. In: Plato (1961), Tom. IV.

Plato $\left(1961^{\mathrm{d}}\right)$. Timaeus. In: Plato (1961), Tom. IV.

Plato (1961 ${ }^{\mathrm{e}}$ ). Epistulae. In:Plato (1961), V.

Weber, M. (1972). Wirtschaft und Gesellschaft. Grundriss der verstehenden Soziologie. Tuebingen. Mohr.

Weber, M.(1973). Wissenschaft als Beruf. In: M. Weber, Gesammelte Aufsaetze zur Wissenschaftslehre. Tuebingen. Mohr. 